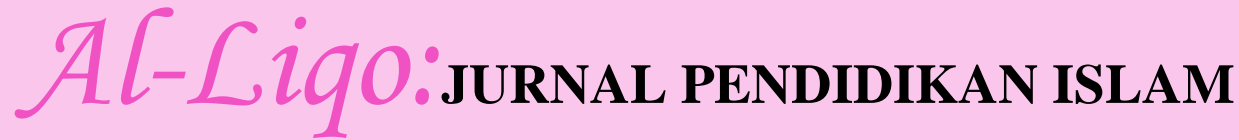 \\ P-ISSN: 2461-033X | E-ISSN: 2715-4556
}

\section{Penggunaan Metode Resitasi dalam Meningkatkan Kualitas Pembelajaran Fiqih di MTS Madrasatul Qur'an Tebuireng Jombang}

*Umi Khumairoh Mawaddah', Iva Inayatul Ilahiyah ${ }^{2}$

${ }^{1}$ Fakultas Agama Islam, Universitas Hasyim Asy'ari (khumairohmawaddah@gmail.com)

${ }^{2}$ Universitas Hasyim Asy'ari (ivailahiyah@gmail.com)

\begin{abstract}
Learning is the activity of delivering knowledge given by educators to students which aims to achieve educational targets. From this learning activity can be determined whether or not the goals of education are achieved. The use of inappropriate methods can cause problems during learning activities. The material that has been delivered by the educator will be in vain because students cannot digest the lesson effectively. The use of the recitation method in learning activities can increase the effectiveness of learning. The purpose of this study is to explain the use of the recitation method or the most effective assignment if applied in MTs Madrasatul Qur'an because it trains students to think and be responsible when carrying out the obligations presented by the educator. Besides directing students to think and be responsible for using the recitation method, it also trains students' independence so that students become more active because they seek or explore knowledge on their own without assistance from the educators. So that the learning objectives are easily achieved and will produce quality learning. In this study the approach used is descriptive qualitative. And the type of research used is field research or field research and uses qualitative research methods. The results of this study indicate that the recitation method can improve the quality of Fiqh learning, it can be seen from the students who are very enthusiastic about participating in learning activities and the increase in the value of student learning outcomes can be seen from the student assignment scores above the KKM score.
\end{abstract}

Keywords: Recitation Method, Quality of Fiqh Learning

\section{Abstrak}

Pembelajaran adalah kegiatan penyampaian ilmu pengetahuan yang diberikan oleh pendidik kepada peserta didik yang bertujuan untuk mencapai target pendidikan. Dari aktivitas pembelajaran inilah dapat ditentukan tercapai dan tidaknya tujuan dari pendidikan. Penggunaan sebuah metode yang kurang pas bisa terjadi kendala saat berlangsungnya kegiatan pembelajaran. Materi yang sudah disampaikan oleh pendidik akan siasia dikarenakan peserta didik tidak bisa mencerna pelajaran secara efektif. Penggunaan metode resitasi dalam kegiatan pembelajaran dapat meningkatkan efektifitas pembelajaran. Tujuan penelitian ini adalah untuk menjelaskan tentang penggunaan metode resitasi atau pemberian tugas paling efektif di MTs Madrasatul Qur'an. Disamping mengarahkan peserta didik untuk berfikir dan bertanggung jawab penggunaan metode resitasi juga melatih kemandirian peserta didik juga agar peserta didik bertambah giat karena mencari atau menggali ilmu pengetahuan sendiri tanpa pendampingan dari pendidik. Sehingga tujuan pembelajaran mudah dicapai dan akan menghasilkan pembelajaran yang berkualitas. Dalam penelitian ini pendekatan yang digunakan adalah deskriptif kualitatif. Dan jenis penelitian yang digunakan ini ialah penelitian field research atau penelitian lapangan serta memakai metode penelitian kualitatif. Hasil dari penelitian ini menunjukkan metode resitasi dapat meningkatkan kualitas pembelajaran fiqih, hal tersebut tampak dari siswa sangat antusias mengikuti kegiatan pembelajaran dan peningkatan nilai hasil belajar peserta didik bisa terlihat dari skor tugas siswa yang rata-rata diatas nilai KKM.

Kata Kunci: Metode Resitasi, Kualitas Pembelajaran Fiqih

\section{Cara Mensitasi Artikel: (APA 6)}

Mawaddah, U. K., \& Ilahiyah, I. I. (2021). Penggunaan metode resitasi dalam meningkatkan kualitas pembelajaran fiqih di MTS Madrasatul Qur'an Tebuireng Jombang. Al-Liqo: Jurnal Pendidikan Islam, 6(2), 184-194. https://doi.org/10.46963/alliqo.v6i2.381

\section{*Corresponding Author: \\ khumairohmawaddah@gmail.com Editorial Address:KampusParitEnam, STAI Auliaurrasyidin Tembilahan.Jl. Gerilya No. 12 Tembilahan Barat, Riau Indonesia 29213.}

\begin{tabular}{|ll|}
\hline \multicolumn{2}{|c|}{ HistoriArtikel: } \\
Diterima $\quad: 25 / 07 / 2021$ \\
Direvisi $\quad:-$ \\
Diterbitkan & $: 31 / 12 / 2021$ \\
\hline
\end{tabular}

DOI:https://doi.org/10.46963/alliqo.v6i2.381 
Penggunaan Metode Resitasi Dalam Meningkatkan Kualitas Pembelajaran Fiqih Di MTs Madrasatul Qur'an Tebuireng Jombang

\section{PENDAHULUAN}

Pembelajaran adalah kegiatan penyampaian ilmu pengetahuan yang dilaksanakan oleh pendidik kepada peserta didik guna menggapai target pendidikan. Dari kegiatan pengajaran inilah dapat ditentukan tercapai dan tidaknya tujuan dari pendidikan.

Menurut Gagne dalam Benny, menjelaskan makna pengajaran sebagai " $a$ set of events embedded in purposeful activities that facilitate learning" Pembelajaran ialah susunan kegiatan yang sengaja dibentuk dengan tujuan untuk mempermudah berlangsungnya kegiatan belajar. (Benny A Pribadi, 2010: 9).

Pembelajaran adalah suatu komunikasi yang dilakukan oleh dua orang atau lebih, proses mengajar dikerjakan oleh pihak pendidik sedangkan proses belajar dikerjakan oleh peserta didik. Pembelajaran menyimpan makna tiap kegiatan yang disusun guna mempermudah seseorang mendapatkan nilai yang baru atau mendalami suatu kecakapan. Metode pembelajaran pada mulanya mengharapkan seorang pendidik memahami keahlian inti yang dipunyai peserta didik yang mencakupi keahlian intinya, semangatnya, background akademisnya, background sosial dan ekonominya, dan sebagainya.

Dalam kandungan surah Al-Alaq ayat 1-5 di jelaskan sebagai berikut:

1. Arahan untuk mempelajari ilmu pengetahuan. Yang di maksud ilmu disini adalah ilmu yang ada dalam Al-Qur'an maupun yang terjadi di alam.

2. Arahan untuk memahami awal mula penciptaan manusia.

3. Perintah untuk menulis ilmu dengan pena yang diperoleh dari berbagai macam ilmu keilmuan dan bisa membagikan pengetahuan yang telah diperoleh kepada orang lain.

4. Allah menciptakan manusia ke dalam dunia pada kondisi yang belum memahami suatu apapun, dan kemudian sedikit demi sedikit mempelajarinya dengan melalui membaca dan menyimak.

Dari wahyu pertama di atas dihasilkan indikasi bahwa terdapat dua macam cara guna memperoleh dan meningkatkan ilmu, yaitu Allah mendidik menggunakan pena yang sudah dipahami manusia pada mulanya dan juga mendidik tanpa menggunakan pena yang belum dipahami modelnya. Maknanya 
Penggunaan Metode Resitasi Dalam Meningkatkan Kualitas Pembelajaran Fiqih Di MTs Madrasatul Qur'an Tebuireng Jombang

ialah bahwa model pertama dengan belajar memakai perantara atau media sebagai inti ikhtiar manusia. Dan model kedua, menyimpan makna bahwa mendidik tanpa memakai media atas dasar ikhtiar manusia. Meski begitu, keduanya berawal dari satu akar, yaitu Allah SWT.

Benjamin S. Bloom dan David Krathwohl dalam Benny, mengutarakan tiga ranah yang bisa difungsikan untuk pondasi guna menyatakan maksud pembelajaran yang melingkupi domain afektif, psikomotor dan kognitif. Target pembelajaran dalam domain kognitif ialah guna membiasakan kesanggupan berfikir pada peserta didik. Target dalam domain ini mencetak siswa yang dapat menghendel pekerjaan dengan kareker intelektualitas. Target pembelajaran pada domain afektif saling terikat dengan perilaku, perasaan, penghormatan atau penghargaan terhadap kaidah, nilai, dan apapun yang sedang dipelajari. Sedangkan untuk target pembelajaran dalam domain psikomotor mempunyai hubungan yang sangat lekat dengan kesanggupan pada saat melaksanakan aktivitas-aktivitas dengan karakter fisik pada berbagai macam mata pelajaran.

Pada tiap siswa mempunyai kelaianan antara satu dengan lainnya. Diantaranya adalah kemampuan dalam memahami materi dan kemampuan menyesuaikan kondisi dengan lingkungan belajar. Dalam kegiatan pembelajaran pasti terdapat masalah seperti siswa yang bermain, berlarian, bermain, bosan, dan lain sebagainya. Hal tersebut terjadi dikarenakan banyak hal, salah satunya adalah penggunaan metode yang tidak tepat. Penggunaan metode yang kurang pas bisa menimbulkan kesulitan saat kegiatan pembelajaran. Materi yang sudah disampaikan oleh guru akan sia-sia sebab peserta didik tidak bisa mencerna pelajaran secara efektif. Seperti pemakaian metode pidato, sedangkan target pembelajarannya ialah supaya siswa bisa mempraktikkan gerakan wudhu dengan baik dan benar, kegiatan pembelajaran seperti tersebut adalah kurang efektif.

\section{METODE}

Dalam penelitian skripsi ini pendekatan yag digunakan ialah pendekatan deskriptif kualitatif, karena informasi yang diperoleh dari berbagai selebaran yang berupa data-data yang dibutuhkan untuk penelitian tidak harus dikuantifikasikan. 
Penggunaan Metode Resitasi Dalam Meningkatkan Kualitas Pembelajaran Fiqih Di MTs Madrasatul Qur'an Tebuireng Jombang

Adapun penelitian deskriptif ialah sebuah penelitian yang dilakukan dengan tujuan guna mendeskriprikan atau menggambarkan kejadian-kejadian dan kaitan antar kejadian yang sedang ditelusuri secara terstruktur, objektif dan seksama tentang realitas dan karakter.

Sumber data sekunder ialah data yang didapatkan melalui sumber yang berupa jurnal, buku, laporan penelitian serta dokumen-dokumen lain yang berkaitan dengan fokus penelitian.

Menurut Berg dalam Hanurawan, ada tiga prosedur analisa data pada penelitian kualitatif, yaitu:

1. Reduksi data

Dalam reduksi data, hal pertama yang dilakukan adalah data di reduksi dan ditransformasi dengan target supaya data lebih mudah untuk dimengerti, mudah terakses dan peneliti juga bisa melihat bentuk awal atau inti awal yang terdapat dalam sebuah data.

2. Penyajian data.

Pemaparan data ini bertujuan untuk mendefinisikan konsep awal dalam sebuah data yang disajikan secara mengelompok dan menggabungkan informasi secara visioner sehingga bisa diambil sebuah kesimpulan.

3. Pembuatan kesimpulan

Pembuatan kesimpulan adalah pengartian pola yang timbul dalam proses analisis data. Kesimpulan tersebut diambil dalam pola yang proposisi mengenai kejadian yang telah diteliti.

\section{HASIL DAN PEMBAHASAN}

\section{Penggunaan Metode Resitasi Dalam Pembelajaran Fiqih Di MTs Madrasatul Qur'an Tebuireng Jombang.}

Hasil observasi dan penelitian memperlihatkan apabila penggunaan metode resitasi dalam pelajaran berjalan dengan efektif. Karena selama kegiatan pembelajaran seluruh peserta didik menyelesaikan tugas yang disampaikan oleh pendidik. Penggunaan metode resitasi digunakan beriringan bersama metodemetode yang lainnya, seperti metode ceramah dan cerita. 
Dalam implementasinya metode resitasi dilakukan setelah guru selesai menjelaskan materi, kemudian memberikan tugas dari materi yang telah di ajarkan tersebut jika setelah menjelaskan tidak ada siswa yang bertanya. Jika tugas telah selesai dikerjakan kemudian guru meminta siswa untuk mengoreksi bersama dan menjelaskan soal yang telah dikerjakan tersebut. Tetapi jika jam pelajaran akan habis, guru yang mengoreksi tugas siswa.

Selain memberikan tugas untuk dikerjakan setelah materi diajarkan, pendidik juga menyampaikan tugas guna diselesaikan di rumah atau di pondok. Agar seluruh peserta didik menyelesaikan tugas yang disampaikan oleh pendidik, ada beberapa konsekuensi yang disampaikan oleh pendidik bagi peserta didik yang tidak menyelesaikan tugas, antara lain dengan mengerjakan tugas yang diberikan.

Kegiatan mengoreksi bersama setelah megerjakan tugas dapat meningkatkan pemahaman siswa, karena dengan mengoreksi bersama, siswa yang awalnya tidak tau kesalahannya menjadi tau. Adapun langkah-langkah penggunaan metode resitasi dalam pembelajaran Fiqih:

a. Pendidik menyampaikan salam

b. Pendidik mempertanyakan kondisi peserta didik

c. Pendidik memberikan motivasi

d. Pendidik menyampaikan materi

e. Pendidik meminta peserta didik untuk bertanya

f. Pendidik menyampaikan tugas kepada peserta didik.

g. Pendidik meminta peserta didik untuk mengoreksi bersama

h. Sambil mengoreksi pendidik memerintah peserta didik untuk menjelaskan tugas yang telah diselesaikan.

i. Pendidik melaksanakan analisis atau penilaian.

Penggunaan Metode Resitasi Dalam Meningkatkan Kualitas Pembelajaran Fiqih Di MTs Madrasatul Qur'an Tebuireng Jombang.

Penggunaan metode dalam pendidikan adalah bagian yang sangat bermakna, karena tanpa menggunakan metode pendidik akan kesusahan untuk menyampaikan pelajaran dan peserta didik akan kesusahan mencerna pelajaran 
Penggunaan Metode Resitasi Dalam Meningkatkan Kualitas Pembelajaran Fiqih Di MTs Madrasatul Qur'an Tebuireng Jombang

yang diberikan oleh peserta didik. Sehingga pemakaian metode harus diselaraskan dengan materi yang bakal diberikan, jadi peserta didik akan mudah mencerna materi yang diberikan oleh pendidik.

Untuk mengukur kualitas suatu metode dalam penerapannya, harus ada parameter yang diimplementasikan untuk standar untuk melihat efektif dan tidaknya metode tersebut. Adapun indikator kualitas pembelajaran sudah diterangkan terlebih dulu, antara lain; aktifitas peserta didik, ketrampilan pendidik mengendalikan pembelajaran, hasil pembelajaran peserta didik, iklim pembelajaran, materi, media pembelajaran, dan sistem pembelajaran di sekolah.

a. Aktifitas siswa

Untuk mengetahui aktifitas siswa selama kegiatan pembelajaran peneliti melakukan wawancara dan observasi, peneliti menggali informasi kepada bapak Fanani selaku guru fiqih di kelas VII terkait dengan aktifitas siswa saat penggunaan metode resitasi dalam kegiatan pembelajaran. Hasil observasi menunjukkan siswa sangat antusias mengikuti kegiatan pembelajaran hal demikian tampak saat seluruh peserta didik menyelesaikan tugas yang disampaikan oleh guru setelah materi selesai di jelaskan, berbeda dengan saat diterapkannya metode ceramah dan cerita ada beberapa siswa yang tidak memperhatikan.

b. Ketrampilan guru mengelola pembelajaran

Dalam mengelola pembelajaran, bapak Fanani menggunakan beberapa metode dalam pembelajaran, seperti metode ceramah, metode diskusi, metode cerita, metode demonstrasi, dan metode resitasi. Penggunaan metode tersebut disesuaikan dengan materi yang disampaikan. Sebelum menggunakan metode resitasi, guru biasanya menggunakan metode ceramah yaitu dengan menjelaskan materi terlebih dahulu. Dan tugas yang diberikan adalah yang berhubungan dengan materi yang sudah diajarkan. Setelah memberikan tugas tersebut pendidik juga meminta peserta didik untuk mempertanggung jawabkan hasil tugas yang telah di kerjakan. Adapun hasil interview tersebut 
dikukuhkan dengan observasi yang dilaksanakan oleh peneliti, yakni cara pendidik dalam memberikan tugas, antara lain:

1) Penyampain pelajaran yang hendak ditugaskan

2) Pendidik meminta peserta didik untuk menanya terkait dengan materi yang sudah diberikan

3) Pendidik meminta peserta didik mengoreksi tugas yang diberikan dan meminta beberapa siswa untuk menjelaskan.

c. Hasil belajar siswa

Untuk bisa melihat apakah metode resitasi atau pemberian tugas berhasil bisa diketahui melalui nilai tugas peserta didik yang sudah meraih nilai KKM. Adapun pada mata pelajaran fiqih kelas VII nilai KKM nya adalah 70.

d. Iklim Pembelajaran

Adapun hasil observasi yang dilakukan peneliti, sebelum menjelaskan materi guru terlebih dahulu memberikan motivasi dengan bercerita untuk membangkitkan semangat belajar siswa. Selama kegiatan pembelajaran sesekali pendidik juga menyiasati dengan gurauan supaya peserta didik tidak merasa jenuh. Begitu pula dengan penggunaan metode, beliau juga menyesuaikan dengan kondisi serta situasi peserta didik agar semua peserta didik bisa mengikuti pelajaran dengan baik serta mampu memahami materi yang telah dipelajari.

Dari hasil interview tersebut, bisa dilihat jika penggunaan metode resitasi diberikan agar ada tangung jawab dari siswa. Jika tidak ada tugas siswa akan meremehkan pembelajaran. Dan tugas yang diberikan kepada siswa tidak diberikan setiap hari karena bisa membuat siswa bosan dan guru telah menyadari hal tersebut.

e. Materi

Berdasarkan hasil observasi dan wawancara, materi yang disampaikan kepada siswa dalam pelajaran fiqih biasanya diambil dari buku LKS dan tugas yang diberikan kepada siswa masih berkaiatan dengan materi yang dipelajari. Selain itu ada materi yang dicarikan sendiri oleh guru, seperti materi untuk praktik khutbah. 
Penggunaan Metode Resitasi Dalam Meningkatkan Kualitas Pembelajaran Fiqih Di MTs Madrasatul Qur'an Tebuireng Jombang

f. Media Pembelajaran

Dalam kegiatan pembelajaran, seorang guru tidak akan lepas dari media pembelajaran. Begitu juga dengan bapak Fanani, beliau juga menggunakan media dalam penyampaian materi yang diajarkan. Dari hasil observasi peneliti, dalam kegiatan pembelajaran Fiqih media yang digunakan antara lain, buku LKS, buku PDF dan juga Papan tulis.

g. Sistem Pembelajaran

Di MTs. Madrasatul Qur'an kurikulum yang digunakan adalah kurikulum 2013 yang dipadukan dengan kurikulum pondok, setelah sebelumnya menggunakan kurikulum KTSP. Dan penerapannya dilakukan secara bertahap tidak secara langsung.

\section{Faktor Pendukung Dan Penghambat Penggunaan Metode Resitasi Dalam Meningkatkan Kualitas Pembelajaran Fiqih Di MTs Madrasatul Qur'an Tebuireng Jombang.}

Dalam kegiatan pembelajaran pasti ada aspek-aspek yang menghambat serta mendukung untuk penggunaan metode pembelajaran karena setiap metode memiliki kelebihan dan kelemahan. Untuk itu penggunaan satu metode dengan metode yang lainnya saling menyempurnakan agar dapat membantu efektifitas pembelajaran.

a. Faktor Pendukung

Dalam pengunaan metode resitasi pasti ada faktor yang mendukung untuk pelaksaannya. Dari hasil wawancara dengan bapak kepala sekolah bapak Jumali Ruslan, menyatakan bahwa salah satu aspek yang membantu aktifitas pembelajaran fikih adalah dikarenakan adanya kesinambungan antara materi fiqih dengan kehidupan sehari-hari saat siswa berada di pondok. Sehingga untuk menjelaskan materi materi tidak terlalu sulit untuk guru.

Selain adanya kesinambungan antara materi fiqih dengan keseharian siswa, ada juga faktor lain yang mendukung penggunaan metode resitasi yaitu rasa tanggung jawab untuk mengerjakan tugas yang diberikan oleh guru. 
Penggunaan Metode Resitasi Dalam Meningkatkan Kualitas Pembelajaran Fiqih Di MTs Madrasatul Qur'an Tebuireng Jombang

b. Faktor Penghambat

Dalam kegiatan pembelajaran pasti tidak lepas dari hambatan dalam pelaksanaannya, begitu juga dengan penggunaan metode resitasi di kelas VII. Banyaknya kegiatan dipondok seperti menghafal Al-Qu'an, nderes, ngaji kitab, dan sebagainya, sehingga tidak ada waktu untuk belajar. Sehingga siswa dituntut untuk faham materi disekolah dan saat di pondok hanya fokus dengan kegiatan pondok. Untuk mengetahui hambatan-hambatan dalam penggunaan metode resitasi, peneliti mewawancarai bapak Jumali Ruslan selaku kepala sekolah.

Jam pelajaran terakhir adalah masa-masa sulit untuk siswa, apalagi setalah melakukan aktifitas dari sebelum subuh. Sehingga di jam-jam terakhir kebanyakan siswa merasa capek. Sehingga untuk memberikan tugas sangat tidak memungkinkan. Adapun menurut bapak Fanani, selaku guru fiqih menjelaskan beberapa hambatan yang dihadapi dalam menerapkan metode resitasi.

Sama halnya dengan pendapat bapak Fanani, bahwa kegiatan di pondok yang padat menjadi kendala siswa untuk mengerjakan tugas.

\section{KESIMPULAN}

Adapun hasil dari penelitian ini bisa dilihat apabila pemanfaatan metode resitasi bisa menaikkan kualitas pembelajaran fiqih di MTs. Madrasatul Qur'an. Hal tersebut dapat terlihat dari nilai tugas peserta didik yang kira-kira diatas nilai Kriteria Ketuntasan Minimal (KKM) dan antusiasme siswa saat mengikuti kegiatan pembelajaran. Penggunaan metode resitasi dapat digunakan sebagai alternatif untuk mengatasi kebosanan siswa dari metode-metode yang lain, agar peserta didik semakin antusias dan lebih rajin dalam aktivitas pembelajaran. Meskipun demikian tidak serta merta menggunakan metode resitasi dalam setiap pertemuan. Dalam kegiatan pembelajaran fiqih penggunaan metode resitasi digunakan bersamaan dengan metode yg lain, seperti metode ceramah. Adapun langkah-langkah penggunaan metode resitasi dalam pembelajaran Fiqih: 
Penggunaan Metode Resitasi Dalam Meningkatkan Kualitas Pembelajaran Fiqih Di MTs Madrasatul Qur'an Tebuireng Jombang

1. Pendidik menyampaikan salam

2. Pendidik mempertanyakan kondisi peserta didik

3. Pendidik memberikan motivasi

4. Pendidik menyampaikan materi

5. Pendidik meminta peserta didik untuk bertanya

6. Pendidik menyampaikan tugas kepada peserta didik

7. Pendidik meminta peserta didik untuk mengoreksi bersama

8. Sambil mengoreksi pendidik memerintah peserta didik untuk menjelaskan tugas yang telah diselesaikan.

9. Pendidik melaksanakan analisis atau penilaian.

Penggunaan metode resitasi dapat meningkatkan kualitas pembelajaran hal tersebut terlihat dari: (a) Aktifitas siswa (b) Ketrampilan guru mengelola pelajaran (c) Hasil belajar siswa (d) Iklim belajar (e) Materi (f) Media pembelajaran (g) Sistem pembelajaran.

Faktor yang mendukung penggunaan metode resitasi adalah karena ada kesinambungan antara keseharian siswa di pondok dengan materi fiqih yang diajarkan di sekolah, adanya rasa tanggung jawab dalam diri siswa untuk mengerjakan tugas selain itu tugas yang akan diberikan dijelaskan terlebih dahulu sehingga siswa mudah memahami soal. Sedangkan faktor penghambat yang utama dalam penggunaan metode resitasi adalah waktu. Karena waktu pembelajaran yang singkat membuat siswa tidak dapat mempertanggung jawabkan hasil tugasnya. Dan jika tugas diberikan di pondok atau take home siswa tidak dapat mengerjakan dikarenakan banyak siswa yang tidak bisa membagi waktu dengan kegiatan di pondok yang padat.

\section{REFERENSI}

Andi Prastowo. (2016). Metode Penelitian Kualitatif Dalam Prespektif Rancangan Penelitian. Jogjakarta: Ar-Ruzz Media.

Benny A Pribadi. (2010). Model Desain Sistem Pembelajaran. Jakarta: Dian Rakyat.

Fattah Hanurawan. (2010). Metode penelitian kalitatif untuk ilmu psikologi. Jakarta: Rajawali Pers. 
Penggunaan Metode Resitasi Dalam Meningkatkan Kualitas Pembelajaran Fiqih Di MTs Madrasatul Qur'an Tebuireng Jombang

Iskandar. (2010). Metode Penelitian Pendidikan dan Sosial (Kuantitatif dan Kualitatif). Jakarta: GP Press.

Sugiono. (2017). Metode Penelitian Kuantitatif, Kualitatif dan RND. Bandung: Alfabeta.

Sumadi Suryabrata. (2010). Metodologi Penelitian. Jakarta: Rajawali Pers.

Syaiful Sagala, Konsep Dan Makna Pembelajaran. Bandung: Alfabeta, 2010

Zainal Arifin. (2011). Penelitian Pendidikan (Metode dan Paradigma Baru). Bandung: Remaja Rosdakarya. 